\title{
Kritik Karl Marx Terhadap kapitalisme Dan Pengertian Sosialisme
}

\section{Sapitri/90100118127}

Kritik Karl Marx terhadap Kapitalisme dimulai dengan Karl Marx menjelaskan tentang nilai guna dan nilai tukar terhadap suatu komoditas atau barang yang dimana menurut pendapatnya bahwa nilai guna adalah suatu barang yang digunakan untuk dipakai sedangkan nilai tukar adalah barang yang memiliki nilai ekonomis dengan kata kali bisa untuk dijual, selain itu Marx menilai bahwa antara pemilik modal dan buruh adalah memiliki antara transaksi yang dapat diperjualbelikan yang terkadang kaum buruh merasa tereksploitasi oleh kaum pemilik modal (Qomar, 2019). Selain itu Karl Marx mengemukakan sebuah ide yang berhubungan dengan kapitalisme yang dimana terdiri atas tiga yaitu manusia, sumber alam dan alat produksi jika digabungkan makanya akan menghasilkan suatu barang dimana diperlukan adanya tenaga kerja, bahan mentah untuk produksi dan alat produksi, jika terjadi permasalahan seperti konflik antara kaum pemilik modal dan kaum buruh maka akan terjadi revolusi sosial atau pemberontakan yang dilakukan oleh kaum buruh karena adanya eksploitasi (Rachmawati, 2020). Karl Marx juga mengkritik terhadap Agama alasannya karena Agama bekerjasama dengan penguasa ekonomi untuk menindas umat manusia dan menganggap agama yang mengajarkan manusia untuk menerima nasib hidupnya menjadi miskin dan terhina yang bekerjasama dengan kapitalis membiarkan kemiskinan terjadi (Bahtiyar \& M. Mu'inudinillah Basri, 2015). Setelah Karl Marx mengkritik terhadap kapitalisme maka lahir yang bernama sosialisme. Yang dimana sosialisme muncul pada awal abad 19 yang merupakan salah solusi terhadap kapitalisme karena kapitalis di anggap gagal mewujudkan masyarakat sejahtera meskipun muncul golongan sosialis ada yang sosialis moderat atau penengah yang masih memperjuangkan idealisme dan adapula sosialis ekstrim yang berusaha mewujudkan idealisme sehingga terjadi revolusi (Wikandaru \& Cahyo, 2016).

Karl Marx mengkritik sistem kapitalisme terhadap proses produksi terbagi atas dua yaitu, nilai tambah yang dimana Karl Marx mengutip dari teori David Ricardo yang mengatakan bahwa terjadi nilai tambah terhadap komoditas bukan karena usaha yang sudah dilakukan melainkan usaha yang dilakukan sebelumnya terhadap alat produksi untuk melakukan kegiatan produksi, selain itu Karl Max menyoroti rumus M-C-M yaitu rumus yang digunakan oleh kaum kapitalis untuk mendapatkan keuntungan sehingga kaum buruh ini merasa tereksploitasi karena harus 
menambah tenaga kerja atau ditingkatkan produktivitas kerjanya sehingga memunculkan kontradiksi karena adanya esensi kapitalisme adalah melakukan penambahan modal dengan cara menambahkan tenaga kerja untuk menghasilkan suatu barang (Kambali, 2020).

Karl Marx juga mengkritik tentang Agama yang menurut pendapatnya bahwa Agama telah memanupulasi manusia terhadap realitas hidup yang sebenarnya atas pengharapan dimasa depan yang bersifat hakiki dan akan abadi di kemudian hari dan menurutnya agama akan membuat manusia akan berpikir lebih jauh dari realitas hidup yang sebenarnya, alasan Karl Marx karena agama mengajarkan memasrahkan kepada keadaan dibandingkan melakukan usaha memiliki materi seperti barang sehingga agama dianggap candu dan pasrah terhadap keadaan meskipun memiliki kekurangan dari segi materi. Setelah Karl Marx mengkritik mengenai sistem kapitalis maka lahirlah yang bernama sosialisme yang dimana sosialisme adalah suatu sistem yang dimana bahwa segala sumber daya alam dan alat produksi adalah kepemilikan bersama sehingga perekonomian dapat dijalankan dengan yang dimana sosialisme memiliki prinsip bahwa setiap orang berhak mendapatkan imbalan atau hasil usaha yang sama sehingga pemerintah ikut mengontrol jalannya perekonomian dari definisi tersebut dijelaskan bahwa sosialisme adalah terjadinya transaksi atau di pasar harus dikontrol melalui perencanaan terpusat yang dilakukan pemerintah. Menurut Tjokrominoto bahwa ia melihat sosialisme dan Islam sebagai penggabungan antara dua pemikiran yaitu ajaran sosialisme yang berasal dari Barat dan ajaran Islam karena menurutnya bahwa Sosialisme adalah cita-cita Islam yang sudah dilakukan sejak lama dan tidak dapat dikatakan bahwa sosialisme muncul dari eropa . Tujuan dari sosialisme adalah untuk menjaga kelangsungan hidup masyarakat dan produksi yang dilakukan tergantung kebutuhan masyarakat (Nurul Cholidiyah dan Richa Angkita Mulyawisdawati, 2018 


\section{DAFTAR PUSTAKA}

Qomar, M. N. (2019). Kritik Karl Marx Terhadap Konsep Buruh Kapitalis Kajian Komparatif Ekonomi Syariah Atas Buku Das Kapital. Annual Conference for Muslim Scholar 3 Kopertais 4, 3(1), 1003-1009.

Rachmawati, F. (2020). Kritik terhadap Konsep Ideologi Komunisme Karl Marx. Jurnal Sosiologi Agama Indonesia (JSAI), 1(1), 66-78.

Bahtiyar, E., \& M. Mu'inudinillah Basri, dan S. H. (2015). Kritik Islam Terhadap Konsep Marxisme tentang Pengentasan Kemiskinan. Profetika, Jurnal Studi Islam, 16(2), 127-135

Wikandaru, R., \& Cahyo, B. (2016). Landasan Ontologis Sosialisme. Jurnal Filsafat, 26(1), 112. https://doi.org/10.22146/jf.1262

Kambali, M. (2020). Pemikiran Karl Marx Tentang Struktur Masyarakat (Dialektika Infrastruktur Dan Suprastruktur). Jurnal Pemikiran Dan Penelitian Ekonomi Islam, 8(2), 63-80.

Nurul Cholidiyah dan Richa Angkita Mulyawisdawati. (2018). Perilaku Produsen Menurut Yusuf Qordhowi dan Karl Marx. Laa Maisyir, 5(2), 68-88. 